\title{
Core components of infection prevention and control programs at the facility level in Georgia: key challenges and opportunities
}

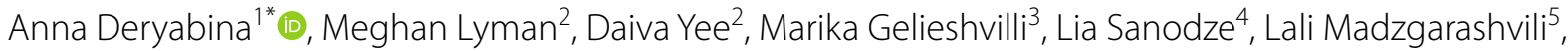
Jamine Weiss ${ }^{2}$, Claire Kilpatrick ${ }^{6}$, Miriam Rabkin${ }^{7}$, Beth Skaggs ${ }^{3}$ and Amy Kolwaite ${ }^{2}$

\begin{abstract}
Background: The Georgia Ministry of Labor, Health, and Social Affairs is working to strengthen its Infection Prevention and Control (IPC) Program, but until recently has lacked an assessment of performance gaps and implementation challenges faced by hospital staff.

Methods: In 2018, health care hospitals were assessed using a World Health Organization (WHO) adapted tool aimed at implementing the WHO's IPC Core Components. The study included site assessments at 41 of Georgia's 273 hospitals, followed by structured interviews with 109 hospital staff, validation observations of IPC practices, and follow up document reviews.

Results: IPC programs for all hospitals were not comprehensive, with many lacking defined objectives, workplans, targets, and budget. All hospitals had at least one dedicated IPC staff member, $66 \%$ of hospitals had IPC staff with some formal IPC training; $78 \%$ of hospitals had IPC guidelines; and 55\% had facility-specific standard operating procedures. None of the hospitals conducted structured monitoring of IPC compliance and only 44\% of hospitals used IPC monitoring results to make unit/facility-specific IPC improvement plans. 54\% of hospitals had clearly defined priority healthcare-associated infections (HAIs), standard case definitions and data collection methods in their HAl surveillance systems. 85\% hospitals had access to a microbiology laboratory. All reported having posters or other tools to promote hand hygiene, $29 \%$ had them for injection safety. $68 \%$ of hospitals had functioning hand-hygiene stations available at all points of care. $88 \%$ had single patient isolation rooms; $15 \%$ also had rooms for cohorting patients. $71 \%$ reported having appropriate waste management system.
\end{abstract}

Conclusions: Among the recommended WHO IPC core components, existing programs, infrastructure, IPC staffing, workload and supplies present within Georgian healthcare hospitals should allow for implementation of effective IPC. Development and dissemination of IPC Guidelines, implementation of an effective IPC training system and systematic monitoring of IPC practices will be an important first step towards implementing targeted IPC improvement plans in hospitals.

Keywords: Infection prevention and control, WHO core components, Facility assessment, Georgia

*Correspondence: annaderyabina@icap.kz; anna@deryabina.com

${ }^{1}$ ICAP, Columbia University, Almaty, Kazakhstan

Full list of author information is available at the end of the article

\section{Background}

Inadequate infection prevention and control (IPC) practices in healthcare hospitals are a main driver of increasing rates of antimicrobial resistance (AMR) and healthcare-associated infections (HAIs) $[5,9,15]$ and are a growing concern for health care and for public health original author(s) and the source, provide a link to the Creative Commons licence, and indicate if changes were made. The images or other third party material in this article are included in the article's Creative Commons licence, unless indicated otherwise in a credit line to the material. If material is not included in the article's Creative Commons licence and your intended use is not permitted by statutory regulation or exceeds the permitted use, you will need to obtain permission directly from the copyright holder. To view a copy of this licence, visit http://creativecommons.org/licenses/by/4.0/. The Creative Commons Public Domain Dedication waiver (http://creativeco mmons.org/publicdomain/zero/1.0/) applies to the data made available in this article, unless otherwise stated in a credit line to the data. 
worldwide [20]. Studies estimate that one in 18 hospitalized patients in Europe and one in 25 hospitalized patients in the United States has a HAI on any given day $[17,33]$.

While HAI data in Georgia are limited, studies suggest transmission of HAIs is an important problem $[7,14,16]$. Georgia has a high prevalence of hepatitis $\mathrm{C}$ virus (HCV) infection associated with healthcare exposures due to inadequate infection control $[11,23]$. In response to the high $\mathrm{HCV}$ prevalence and growing concerns around AMR, the Georgia Ministry of Labor, Health, and Social Affairs (MoLHSA) instituted the National Strategy for Combating Antimicrobial Resistance and the Hepatitis C Elimination Program, which includes a focus on strengthening IPC and reducing healthcare transmission.

Healthcare transmission of AMR and HAIs can be prevented through comprehensive and robust IPC programs $[4,31,32]$. To support countries' efforts to strengthen IPC, the World Health Organization (WHO) released their new evidence-based guidelines on IPC core components in 2017 [32, 36]. These guidelines cover eight areas of IPC and include 14 recommendations and best practice statements.

A number of MoLHSA decrees exist that describe facility-level IPC requirements and are treated as National IPC guidelines. However, the decrees are fragmented and only provide general IPC recommendations. Information about necessary infrastructure and implementation of IPC at Georgian healthcare hospitals is limited and only covers the built environment or HAI epidemiology and etiology. To address these gaps, ICAP at Columbia University in close collaboration with the U.S. Centers for Disease Control and Prevention (U.S. CDC), and WHO used a modified version of the draft WHO IPC Assessment Framework (IPCAF) tool to conduct a systematic assessment of IPC practices in Georgia. This study is the first formal and systematic assessment of IPC core components at the facility level in Georgia.

\section{Methods}

\section{Study protocol}

The study protocol was approved by the Institutional Review Boards (IRB) of Georgia's National Center for Disease Control and Public Health (NCDC) and Columbia University Medical Center. This project was reviewed in accordance with the U.S. CDC human research protection procedures and was determined to be nonresearch. Participation in the study was voluntary and informed consent was sought from all participants, with the option to withdraw consent at any time. Respondents were informed that results of the assessment would be presented to the MoLHSA in the form of a summarized report with no data on individual hospitals included.
There were no refusals to participate in the study. No compensation for participation was provided.

\section{Hospital selection}

A random sample of inpatient hospitals, stratified by geographic region and service status (i.e. public, private), was selected to ensure proportional representation. Three multi-specialty hospitals from hospital networks not included in the random sample were added to ensure representation of all private hospital networks. Small hospitals, defined as multi-specialty hospitals with less than 20 beds and specialty hospitals with less than 10 beds, were excluded. Hospitals providing only psychiatric services or tuberculosis treatment were also excluded because of the specialized care and unique IPC issues.

\section{Pilot study and data collection}

The assessment tool used was adapted from the IPCAF issued by WHO in 2018 to support the implementation of the WHO Guidelines on Core Components of IPC Programs at the National and Acute Health Care Facility Level [37, 38]. A study published in 2020 highlights that effective utilization of the IPCAF tool requires a deep understanding of the WHO terminology and underlying concepts to avoid misinterpretation and misreporting of data [34]. To improve quality of data and avoid biased reporting, the team adapted the IPCAF tool for the situational assessment in Georgia. For that, the study team conducted several meetings with local specialists involved in IPC and external IPC experts from the U.S. $\mathrm{CDC}$ and $\mathrm{WHO}$ to review the questions, select those that were relevant to Georgia, and add additional questions providing more details or verification. The revised questionnaires (Annex 2) were then transferred into ICAP's online survey data collection system (e-Survey) and piloted at two hospitals located in the capital Tbilisi, not included in the study sample. Results of the pilot were used to revise the questionnaires and data collection procedures.

Data were collected during March 2018 by a team of local specialists involved in IPC implementation, monitoring, and training. All data collectors received a two-day training by ICAP at Columbia University in protocol implementation, interviewing techniques and ethical considerations. All healthcare facility assessments were conducted during a one-day visit by two study team members. The first part of the assessment consisted of key informant interviews, conducted in Georgian, with hospital managers and the facility IPC teams, and included a review of the facility's available IPC-related documents. Individual and small group structured interviews were conducted at 41 hospitals and included 109 facility staff, including 51 facility managers and 58 IPC 
team members (i.e., nurses, epidemiologists, physicians). Disagreements around answers to the same questions for the same hospital were resolved by facilitating a discussion among hospital IPC team members to reconcile discrepancies until a final answer was agreed upon and recorded. During the second part of the assessment, the study team conducted a facility walk-through using observations to verify answers provided during the interviews. Data were entered into a tablet computer using e-Survey. Answers to open-ended questions were audio recorded and then transcribed in Georgian and translated into English for analysis.

\section{Data analysis and reporting}

Descriptive analysis was conducted for categorical data using frequency analysis and cross-tabulation. Qualitative data from key informant interviews were grouped into meaningful patterns and/or themes through content and thematic analysis using $\mathrm{NVivo}^{\odot}$. Further analysis of each theme was undertaken using a three-step approach, "describe, compare, relate" [6]. Data from individual interviews were either linked with data from the document review and facility observations to allow for multidimensional descriptions of IPC core components at the facility level or integrated with each other to produce a fuller picture of IPC core components at the facility level [21].

A final written report was shared with the MoLHSA. A national IPC stakeholder meeting, which included national and facility leaders, was conducted by the MoLHSA in collaboration with the U.S. CDC and WHO. The meeting included a presentation of preliminary survey findings, expert opinion on interpretation of the data, and open discussions on the need to strengthen IPC and develop partnership between all levels to improve IPC implementation in Georgia.

\section{Results}

The assessment included 41 hospitals (31 multi-specialty hospitals and 10 specialized hospitals), covering $15 \%$ of all hospitals in Georgia. Among these hospitals, the average bed capacity was 73 beds per facility (range 10-230 beds). Key assessment findings related to facility-level IPC system characteristics as recommended by WHO are discussed in the text below. Detailed assessment results are presented in Annex 1.

\section{IPC program components}

Of the 41 hospitals participating in the assessment, 38 (93\%) had an IPC program. However, none of the IPC programs had all the WHO-recommended elements including clearly defined objectives based on local epidemiology, annual IPC workplans, adequate improvement measures and targets, and a specified IPC budget.

All hospitals included in the assessment had an IPC team, 32 (78\%) hospitals had more than one IPC team member and 34 (83\%) hospitals had at least one fulltime IPC specialist. At least one IPC team member in 27 hospitals (66\%) had received some formal IPC training. During interviews, absence of dedicated, full-time IPC nurses, lack of IPC certified courses and limited professional development opportunities for IPC personnel were cited as key barriers to adhering to the WHO Core Component recommendations.

Of the hospitals included in the assessment, 39 (95\%) hospitals reported having an IPC committee consisting of a multidisciplinary group that advises the IPC team. IPC committees at every facility included senior leadership (e.g., administrative director, the chief executive officer, medical director) and senior clinical staff (e.g., chief physician, chief of nursing). Additionally, IPC committees at 28 of the 39 hospitals (72\%) included facility management staff, such as biosafety, water, sanitation, and hygiene (WASH) staff. Thirty-eight of the 39 hospitals (93\%) reported their committee met at least once in the past 12 months. However, documentation of IPC committee meetings, as evidenced by meeting notes, was available at only in 19 of 38 (50\%) hospitals.

Thirty-five (84\%) of the 41 hospitals had access to microbiology laboratory within or outside of the facility for day-to-day use. Hospitals located in urban areas had more access to microbiology laboratories compared to rural hospitals, ( $77 \%$ vs. $23 \%)$.

\section{IPC training}

Thirty-seven (90\%) of 41 hospitals had conducted IPC trainings in the previous 12 months. Most hospitals trained clinical and non-clinical staff on IPC, however, ongoing IPC annual training for clinical staff was required at $54 \%$ of hospitals. Nine (22\%) of 41 hospitals conducted IPC trainings for all clinical staff as part of new employee orientation in addition to mandatory refresher trainings at least annually. Eight (20\%) of 41 hospitals conducted IPC trainings for all non-clinical staff during orientation as well as regular mandatory refresher trainings at least annually. During individual interviews, IPC focal persons mentioned lack of regular IPC training for clinicians and the need for technical assistance to develop IPC training programs at their facility as challenges to implementing IPC.

\section{IPC monitoring and audit}

Seven (17\%) hospitals had an IPC monitoring/audit plan available, however none of these plans had all the necessary elements, such as clear goals and objectives, tools 
to systematically collect data, clearly defined roles and responsibilities, and a work plan or schedule. Thirtytwo of $41(78 \%)$ hospitals reported conducting internal monitoring/audits in the last 3 months, 20 of 41 (49\%) hospitals surveyed provided documentation of these monitoring/audits. Among these 20 hospitals, none conducted internal monitoring/audits at least once a month for each category of IPC practices. Only 17 (41\%) conducted monitoring/audit in the past 12 months and shared the results with all cadres of facility staff, including clinical and non-clinical staff, IPC committee and facility management.

\section{HAl surveillance}

Thirty-one of 41 (76\%) hospitals reported conducting HAI surveillance. However, none of the hospitals reported having a system that include all HAI surveillance components recommended by WHO including a list of priority HAIs, standardized case definitions, standardized data collection and review methods, and clearly defined roles and responsibilities.

\section{IPC guidelines}

Thirty-one (76\%) of the 41 hospitals had IPC guidelines available, including $26(63 \%)$ that used national guidelines, two $(5 \%)$ that used international guidelines translated into Georgian, and three (7\%) that used internal guidelines developed by their own facility staff. Of the total sample, $18(44 \%)$ reported training their clinical staff on the IPC guidelines. Thirty-three (80\%) hospitals had IPC SOPs available, 18 (55\%) of which had facilityspecific SOPs adapted by IPC personnel and clinical staff.

\section{Multimodal strategies}

Facility use of multimodal strategies for hand hygiene $(\mathrm{HH})$ and injection safety were assessed. Injection safety was specifically targeted given the high prevalence of $\mathrm{HCV}$ in Georgia. While all hospitals reported having reminders, posters, or other tools to promote hand hygiene, only 19 (46\%) hospitals displayed them at all hand hygiene stations. Four (10\%) hospitals used additional methods to improve team communication for hand hygiene across units. Twelve (29\%) of hospitals reported having reminders, posters, or other tools to promote injection safety with only four hospitals $(10 \%)$ had visible reminders, posters, or other tools to raise awareness of injection safety at all stations. Managers showed visible support and served as role models for hand hygiene in 23 (56\%) hospitals and for injection safety in 21 (51\%) hospitals.

\section{IPC infrastructure and supplies}

Most hospitals reported having the basic infrastructure and supplies needed to conduct IPC including building features, such as energy and water supply (100\%), bed occupancy limited to one patient per bed in all units (100\%), adequate spacing (at least $1 \mathrm{~m}$ ) ensured between beds in all units (88\%), and functioning environmental ventilation available in all patient care areas (98\%). Thirty-six hospitals (88\%) had single rooms available for individual isolation. Thirty-seven hospitals (90\%) had dedicated decontamination area and/or sterile supply department available and functioning, and 40 hospitals (98\%) reported to have sterile and disinfected equipment ready for use every day and of sufficient quantity.

However, for many hospitals, responses to interview questions were inconsistent with infrastructure and supply observations. For example, 21(51\%) hospitals reported having a daily record of cleaning, but the daily record was verified by data collectors' observations in 13 (32\%) hospitals. Similarly, 37 (90\%) hospitals reported having functioning hand hygiene stations available at all points of care, but data collectors were only able to verify through their observations in $28(68 \%)$ hospitals. Almost all hospitals (98\%) reported having functional waste collection containers available at all waste generation points, however these were observed in only 29 (71\%) hospitals.

In interviews, several facility managers from rural hospitals cited poor infrastructure (i.e., lack of rooms, need for complete renovation of premises, broken sewage systems) and absence of funding to improve infrastructure as leading factors preventing effective IPC implementation at their hospitals.

\section{Discussion}

Overall, this study showed that the presence of an IPC program in Georgia does not directly correlate to a wellfunctioning facility-level IPC system where core IPC components are present.

Specifically, we found challenges in IPC-related staffing and training. While most hospitals had a sufficient number of designated IPC staff, nurses were part of the IPC team at only $78 \%$ of hospitals, despite recommendations for all IPC teams to include nurses [24]. In addition, IPC staff had received formal training at only $66 \%$ of hospitals surveyed; less than a third of hospitals routinely trained all new clinical and non-clinical staff as well as conducted mandatory IPC training at least annually. Only $76 \%$ of hospitals surveyed had any IPC guidelines, most were using national IPC guidelines that were not locally adapted, and only $58 \%$ of hospitals with IPC guidelines conducted related trainings. These findings correlate with research conducted previously at nine Georgian maternity hospitals showing that less than $70 \%$ of clinical 
staff received any type of training on HAI and that trainings conducted were limited to short seminars or ad hoc presentations [8]. Lack of effective capacity building for the healthcare workforce in Georgia is not unique to IPC, several other reviews have found inadequate training of healthcare providers to be a key challenge to quality health care services (Akhvlediani, Akhvlediani, \& Kuchuloria, 2016; [16, 22, 29]. Suboptimal IPC education and training is also not unique to Georgia, as similar shortcomings were demonstrated during surveys conducted in high-income settings like Germany and Austria $[1,2]$.

Our findings also show that very few hospitals in Georgia used any systematic tools to routinely monitor IPC practices. Regular monitoring of IPC practices and timely feedback to all relevant staff is critical to prevent and control HAI at the facility-level [36]. Evidence shows a relationship between monitoring of hand-hygiene practices and reduced rates of HAI [10, 13, 25, 39], and WHO recommends monitoring all critical aspects of IPC, such as interventions to prevent catheter-related bloodstream infections and ventilator-associated pneumonia, as well as auditing of environmental cleaning procedures. Sharing of information with relevant facility staff was also rare. This is consistent with a 2016 review noting that due to limited training and monitoring, medical staff often neglected proper hand washing and use of personal protection equipment [3].

To our knowledge, this is the first systematic assessment of WHO's IPC core components at Georgian health hospitals. Previously published studies focused on HAI and AMR epidemiology, including neonatal blood stream infections [16, 30], multi-drug resistant tuberculosis $[19,35]$, and specific pathogens such as antibiotic resistant Staphylococcus aureus, Pseudomonas aeruginosa, and Enterococcus spp. [26]. None of the published studies, however, used a systematic approach to evaluate the organization and implementation of IPC at the facility level.

There are limitations to this assessment. Hospitals were randomly selected to include those of different geographic locations, types, and sizes. Although the response rate for the selected facilities was $100 \%$, specialized hospitals for treatment of psychiatric conditions and tuberculosis, specialized hospitals with less than 10 beds, and general hospitals with less than 20 beds were excluded from the study, therefore, the results cannot be considered nationally representative. While data collectors informed participants that results would not be used to evaluate individual hospitals and would not result in punitive actions, staff may have been reluctant to share deficiencies. For areas where direct observations were not made, the assessment team verified the answers by cross-checking the available hospital documentation, however, over-reporting of presence of certain IPC components still likely occurred. Despite efforts to provide contextual information to participants, confusion about new or unfamiliar concepts may have affected the accuracy of their answers.

Strengths of this assessment include its focus on the gap between IPC policy and IPC implementation, as well as its relatively large sample size and systematic approach to data collection. This survey highlights that the presence of an IPC committee or policy do not always translate into functioning IPC activities at hospitals in Georgia. The results also highlight the challenges that can occur even in a country with a national IPC strategy. They highlight the need for ongoing systems strengthening at both the facility level and the national level. Development and dissemination of IPC Guidelines, implementation of an effective IPC training system and systematic monitoring of IPC practices will contribute to improved IPC in the country.

\section{Conclusions}

Our study shows that most of Georgian hospitals we surveyed have parts of an effective IPC program, namely an IPC committee, an IPC policy, designated staff and basic infrastructure in place; however, this does not translate into functional IPC activities. Georgia is reforming their healthcare system to ensure universal health coverage (UHC) and improve the quality of healthcare services, but achieving UHC with quality health services is not possible without an effective IPC system [31]. Endorsement of this study by the MoLHSA is an important step in Georgia's commitment to improving IPC and adhering to WHO's IPC Core Components. There are resources available which provide practical tools for strengthening IPC programs at the national and facility level, based on the WHO IPC Core Components, and addressing the gaps identified during this assessment [37, 38].

Georgia is currently updating national IPC guidelines, based on international standards, but adapted to the Georgian context. This is an initial step to establishing national IPC standards, upon which to base the development of IPC trainings and an IPC monitoring system. A comprehensive IPC monitoring system at the facility and national level is critical to ensure compliance and guide future IPC improvements. Continuous improvement will require regular monitoring and use of IPC data.

\section{Abbreviations}

AMR: Antimicrobial resistance; DQA: Data quality audit; HAl: Health careassociated infections; IICP: International Infection Control Program; IPCAF: IPC Situational analysis Framework; IPC: Infection prevention and control; IRB: Institutional review board; MoLHSA: Ministry of Labor Health and Social Affairs of Georgia; NCDC \& PH: National Centers for Disease Control \& Public Health, Georgia; PI: Principal investigator; SOP: Standard operating procedure; 
U.S. CDC: U.S. Centers for Disease Control and Prevention; WHO: World Health Organization.

\section{Acknowledgements}

This situational analysis would not have been possible without the support from the MoLHSA leadership and participation of staff from healthcare hospitals included in the assessment. In addition, the following individuals were essential to the development and implementation of the assessment: Marina Baidauri (MoLHSA), Tina Gabrichidze (Tbilisi State Medical University), Gvantsa Gasviani (MoLHSA), Eka Khabazi (NCDC \& PH), Shorena Svanidze (Tbilisi Republican Hospital), Lela Tsakadze (EVEX), Sarina Dane (ICAP), Nadria Erkebaeva (ICAP), Viktor Ivakin (ICAP), Getachew Kassa (ICAP), Brenda Senyana (ICAP), Ketie Zaridze (NCDC \& PH).

\section{Disclaimer:}

The findings and conclusions in this report are those of the author(s) and do not necessarily represent the official position of the U.S. Centers for Disease Control and Prevention or the WHO.

\section{Authors' contributions}

$\mathrm{AD}$ contributed to the design, data collection, analysis, and interpretation of data, and drafted the article. MG, LS and LM contributed to data collection. DY contributed to data analysis. ML, JW, MR, CK, BS and AK contributed to the conception, design of the study and revised the article for content and language. All authors read and approved the final manuscript.

\section{Funding}

This study was funded by the U.S. Centers for Disease Control and Prevention (CDC) through the Global Technical Assistance Project, Cooperative
Agreement \# 5U2GGH000994-03, Year 5. Funding period 04/01/201803/31/2019, President's Emergency Plan for AIDS Relief (PEPFAR). CDC staff were involved in protocol development, implementation and report writing.

\section{Availability of data and materials}

The authors are responsible for the data described in the manuscript and assure full availability of the study material upon request to the corresponding author.

\section{Ethics approval and consent to participate}

The study protocol was reviewed and approved by the Columbia University Medical Center IRB, IRB of Georgia National Center for Disease Control and Public Health.

\section{Consent for publication}

Not applicable.

\section{Competing interests}

Authors have no competing interests to disclose.

\section{Author details}

${ }_{1}^{1}$ ICAP, Columbia University, Almaty, Kazakhstan. ${ }^{2}$ International Infection Control Program, Division of Healthcare Quality Promotion, U.S. Centers for Disease Control and Prevention, Atlanta, USA. ${ }^{3}$ South Caucasus Office, U.S. Centers for Disease Control and Prevention, Atlanta, USA. ${ }^{4}$ MoLHSA/NCDC\&PH, Atlanta, USA. ${ }^{5}$ TEPHINET, Atlanta, GA, USA. ${ }^{6}$ Consultant to the World Health Organization, Geneva, Switzerland. ${ }^{7}$ ICAP, Columbia University, New York, USA. 


\section{Annex 1: Assessment of IPC system characteristics}

IPC program components

Annual work plan

Measurable outcomes

Sufficient IPC budget

\section{IPC team components}

IPC team includes more than one staff member

IPC Training

\section{IPC training participants}

Clinical staff

Family members, care-givers or visitors

\section{Frequency of IPC training}

Staff trained as part of new employee orientation

Clinical staff

Non-clinical staff

Ongoing mandatory training at least annually

Clinical staff

Non-clinical staff

Other characteristics of IPC training

IPC training included interactive sessions

Monitoring of which clinical and non-clinical staff had

been trained in IPC

IPC Monitoring and audit

IPC monitoring/audit plan

Components of monitoring/audit plan

Clear goals and objectives

Tools to collect data in a systematic way

Clearly defined roles and responsibilities

Work plan or schedule

Monitoring results were used to make unit/facility-specific plans to improve IPC practices

Frequency of internal monitoring/auditing

At least once within the past 3 months

At least once within the past 6 months

At least once within the past 12 months

More than 12 months ago or never

Conducted and documented internal monitoring/auditing within the past 12 months

Hospitals conducting internal monitoring/audits at least once a month, by IPC practice

Hand Hygiene compliance

Consumption/usage of alcohol-based hand rub or soap $1(2)$

Injection safety

Waste management

Cleaning of ward environment 
Wound dressing change

\section{Sharing IPC monitoring/audit results (oral or written) with different staff types in the past 12 months}

Clinical staff

Non-clinical staff that have direct contact with patients

Clinical managers/heads of department

IPC committee member

Non-clinical management (CEO, administration, board)

HAl surveillance

Reported conducting HAl surveillance

\section{HAI surveillance components}

List of priority HAls which are major causes of morbidity and mortality in the facility 15 (37)

Standardized case-definitions (defined numerator and denominator) 13 (32)

Standardized data collection methods 14 (34)

Processes to review data quality 6 (15)

Clearly defined roles and responsibilities of staff involved in surveillance 6 (15)

Annual work plan and schedule 3 (7)

Surveillance system includes none of the above components 7 (22)

IPC guidelines

\section{Types of IPC guidelines}

International guidelines that have not been adapted to facility context (translated into Georgian)

National guidelines

Facility develops own guidelines

\section{IPC guideline training}

Trainings included written information and/or oral instructions

Trainings included interactive sessions

Multimodal strategies

\section{Hand hygiene}

System change

Education and training on IPC practices

Monitoring of compliance and feedback

Communication and reminders

Safety climate and culture change

\section{Injection safety}

System change

Education and training on IPC practices

Monitoring of compliance and feedback

Communication and reminders

Safety climate and culture change
Interventions to ensure the necessary infrastructure and continuous availability of supplies Interventions to ensure optimal use and accessibility and prevent human error 
IPC infrastructure and supplies

Appropriate building features
Bed occupancy limited to one patient per bed in all units

$41(100)$

Patients never placed outside in corridor

$41(100)$

$36(88)$

Adequate spacing $(>1 \mathrm{~m})$ ensured between beds in all units

$41(100)$

Sufficient energy supply is available for all uses in all areas

40 (98)

Functioning environmental ventilation available in all patient care areas

$39(95)$

Water services available at all times and in sufficient quantities for all uses

40 (98) wards

Functioning hand hygiene stations available at all points of care

Sufficient number of toilets/latrines available

Sufficient PPE* available per each cleaning/waste disposal staff

Personal protective equipment

Dedicated decontamination area and/or sterile supply department available and functioning

$37(90)$

Reliably have sterile and disinfected equipment ready for use every day and of sufficient quantity

Single rooms available for isolation

$40(98)$

$36(88)$

Rooms available for cohorting patients with similar pathogens if single rooms are unavailable

Functional waste collection containers available for non-infectious, infectious, and sharps waste at all waste generation points

Functional burial pit/fenced waste dump or municipal pick-up available for disposal of noninfectious waste

Outsourced waste disposal, incinerator, or alternative treatment functional and available for infectious and sharps waste

Wastewater safely managed using on-site treatment or sent to a functioning sewer system

40 (98)

cesses

Visible record of cleaning completed and signed daily

$41(100)$

$41(100)$

Cleaning of the environment

Appropriate and well-maintained materials for cleaning available

\section{Annex 2A: Questionnaires used for semi-structured interviews with health managers}

\begin{tabular}{|c|c|c|c|}
\hline \# & Question & Answer & Skip \\
\hline 1 & Does your facility have an IPC programme? & $\begin{array}{l}\text { 1. No } \\
\text { 2. Yes }\end{array}$ & \\
\hline 2 & $\begin{array}{l}\text { Does your facility have a budget specifically allocated to the IPC programme } \\
\text { (e.g. to address IPC materials, administrative support, staff)? }\end{array}$ & $\begin{array}{l}\text { 1. No } \\
\text { 2.Yes }\end{array}$ & \\
\hline 3 & $\begin{array}{l}\text { Is there an IPC team with one or more IPC staff with dedicated time for IPC } \\
\text { activities? }\end{array}$ & $\begin{array}{l}\text { No } \\
\text { Yes }\end{array}$ & SKIP to 5 \\
\hline 4 & $\begin{array}{l}\text { Does the IPC team have at least one full-time IPC specialist (a nurse or a doc- } \\
\text { tor or an epidemiologist) working 100\% on IPC? }\end{array}$ & $\begin{array}{l}\text { 1. All IPC staff work part-time on IPC } \\
\text { 2. } 1 \text { or more full-time IPC specialist for } 250 \\
\text { beds and less } \\
\text { 3. Less than } 1 \text { full-time IPC specialist for } \\
250 \text { beds and less }\end{array}$ & \\
\hline 5 & $\begin{array}{l}\text { Do you have an established IPC Committee or an equivalent actively support- } \\
\text { ing the IPC team? }\end{array}$ & $\begin{array}{l}\text { 1. No } \\
\text { 2. Yes }\end{array}$ & \\
\hline 6 & $\begin{array}{l}\text { When was the last time you led or participated in a meeting to discuss IPC- } \\
\text { related objectives, targets and challenges? }\end{array}$ & $\begin{array}{l}\text { 1. Never } \\
\text { 2. More than } 3 \text { months ago } \\
\text { 3. Within the past } 3 \text { months }\end{array}$ & \\
\hline 7 & $\begin{array}{l}\text { Are there any vaccines that are required for healthcare workers at your facility? } \\
\text { Please mark all that apply }\end{array}$ & $\begin{array}{l}\text { 1. No required vaccinations } \\
\text { 2. Hepatitis B for all previously unvac- } \\
\text { cinated } \\
\text { 3. Annual influenza vaccine } \\
\text { 4. MMR for those with no serologic evi- } \\
\text { dence of immunity or prior vaccinations } \\
\text { 5. Other }\end{array}$ & \\
\hline 8 & What do you consider the top challenges to implementing IPC at this facility? & & \\
\hline 9 & $\begin{array}{l}\text { What would be your recommendations to improve IPC in this facility? } \\
\text { Probe: At the national (maybe regulatory level)? } \\
\text { Probe: At the facility level? }\end{array}$ & & \\
\hline
\end{tabular}




\section{Annex 2B: Questionnaires used for semi-structured interviews with IPC FOCAL POINT/TEAM}

\section{PART 1}

\begin{tabular}{|c|c|}
\hline \# & Question \\
\hline 1 & $\begin{array}{l}\text { Does your facility have an IPC programme? } \\
\text { Choose one answer } \\
\text { Please ask for all the documents that support the answer. } \\
\text { Review the document(s) together with the respondents and answer } \\
\text { questions } 1 \mathrm{~A}-\mathrm{C} \text {. }\end{array}$ \\
\hline $1 \mathrm{~A}$ & $\begin{array}{l}\text { Does the existing IPC programme have clearly defined responsibilities } \\
\text { and annual work plan? } \\
\text { SELECT ALL THAT APPLY }\end{array}$ \\
\hline $1 \mathrm{~B}$ & $\begin{array}{l}\text { Does the existing IPC programme have clearly defined IPC objectives } \\
\text { for the facility? } \\
\text { Choose one answer }\end{array}$ \\
\hline
\end{tabular}

Answer

1. No

2. Yes

1. No

2. The existing program has clearly defined responsibilities

3. The existing program has annual work plan

1. No

2. Yes, IPC objectives, but there is no evidence that they are based on local epidemiology and priorities according to risk assessments

3. Yes, IPC objectives based on local epidemiology and priorities according to risk assessments

1C Does the existing IPC programme have clearly defined IPC measurable outcome indicators for the facility?

Choose one answer

1. No

2. Yes, IPC measurable outcome indicators (or adequate measures for improvement)

3. Yes, IPC, measurable outcome indicators and future targets

2 Does your facility have a budget specifically allocated to the IPC programme (e.g. to address IPC materials, administrative support, staff)? 2. Yes Choose one answer

3 Do you consider the budget allocated for IPC as sufficient to cover your needs?

3. Don't know

1. No

2. Yes

\section{Choose one answer}

Is there an IPC team with one or more IPC staff with dedicated time for 1. No

$$
\begin{array}{ll}
\text { IPC activities? } & \text { 2.Yes }
\end{array}
$$

Choose one answer

5 How many staff (nurses and/or doctors and/or epidemiologists and/or others) working on the IPC team?

Please ask for a copy of the Terms of Reference for the Team or the IPC Focal point and the document that certifies their appointment.

Does the IPC team have at least one full-time IPC specialist (a nurse and/or a doctor and/or an epidemiologist/other) working 100\% on IPC?

Choose one answer

Please verify the answer based on the available documents.

$7 \quad$ Have members of your IPC team received formal IPC course training? Choose one answer

Please ask for any documents that would verify the answer

epidemiologist

nurses

physicians

others

1. All IPC staff work part-time on IPC

2. 1 or more full-time IPC specialist for 250 beds and less

3. Less than 1 full-time IPC specialist for 250 beds and less

1. None were trained

2. Some were trained

3. All were trained

1. No professional development offered

2. IPC members attend IPC-related conferences or workshops

3. IPC members attend IPC-related training courses

1. No

2. Yes the IPC team?

Choose one answer

Please ask for a copy of the document appointing members of an Infection Control Committee.

10 Which, if any, of the following professional groups are represented or included in the IPC Committee or an equivalent?

SELECT ALL THAT APPLY

Please verify the answer based on the available documents.

1. Facility management (e.g. administrative director, chief executive officer (CEO), medical director)

2. Senior clinical staff (e.g. chief physician, chief of nursing)

3. Other facility management [e.g. biosafety, waste, those tasked with addressing water, sanitation and health (WASH)] 


\begin{tabular}{|c|c|c|c|}
\hline$\#$ & Question & Answer & Skip \\
\hline$\overline{11}$ & $\begin{array}{l}\text { Did the committee meet in the past } 12 \text { months? } \\
\text { Choose one answer }\end{array}$ & $\begin{array}{l}\text { 1. No } \\
\text { 2. Yes }\end{array}$ & SKIP to 13 \\
\hline 12 & $\begin{array}{l}\text { Did you keep notes for the IPC committee meetings conducted in the } \\
\text { past } 12 \text { months? } \\
\text { Choose one answer } \\
\text { If yes, please ask for a copy of meeting notes from all the meetings } \\
\text { conducted during the past } 12 \text { months and verify the answer. }\end{array}$ & $\begin{array}{l}\text { 1. No } \\
\text { 2. Yes, for some } \\
\text { 3. Yes, for all }\end{array}$ & \\
\hline 13 & $\begin{array}{l}\text { When was the last time someone from the facility management, led } \\
\text { or participated in a meeting to discuss IPC-related objectives, targets } \\
\text { and challenges? } \\
\text { Choose one answer } \\
\text { Please verify the answer based on the available documents. }\end{array}$ & $\begin{array}{l}\text { 1. Never } \\
\text { 2. More than } 3 \text { months ago } \\
\text { 3. Within the past } 3 \text { months }\end{array}$ & \\
\hline 14 & $\begin{array}{l}\text { Does your facility have microbiological laboratory support for routine } \\
\text { day-to-day use? } \\
\text { Choose one answer }\end{array}$ & $\begin{array}{l}\text { 1. No } \\
\text { 2. No, but the facility has access to a clinical laboratory at } \\
\text { another site } \\
\text { 3. Yes, an on-site laboratory is available }\end{array}$ & \\
\hline
\end{tabular}

\section{IPC Trainings}

Next, I would like to discuss the IPC trainings available to your staff. We will cover trainings that are part of new employee orientation and continuous educational opportunities for existing staff, regardless of level and position, for example trainings for senior administration and housekeeping staff. Trainings can include classroom, e-learning, bedside, and simulation training. We will also discuss periodic evaluations conducted to determine the effectiveness of your facility's training programmes and assess staff knowledge

15 Did this facility conduct any IPC trainings for clinical staff and others having contact with patients or wards during the past 12 months? SELECT ALL THAT APPLY

Please ask for copies of all training materials (agenda and list of participants) from all IPC-related trainings conducted during the past 12 months

Does this facility keep track of which clinical and non-clinical staff have been trained in IPC?

Choose one answer

Please verify the answer based on the available documents. If there is no documented proof that they track training participation, please mark No

17 Did IPC trainings for clinical and non-clinical staff conducted during the past 12 months include interactive training sessions (simulations and/or bedside trainings)?

Choose one answer

Please verify the answer based on the available documents. If not verified, then mark a different answer

18 Who led IPC trainings for clinical and non-clinical staff conducted during the past 12 months?

SELECT ALL THAT APPLY

Please verify the answer based on the available documents.

19 How did you assess the effectiveness of IPC trainings conducted during the past 12 months?

SELECT ALL THAT APPLY

Please verify the answer based on the available documents.

20 In general, which statement best describes when IPC training for clinical staff at your facility is delivered?

SELECT ALL THAT APPLY

Please verify the answer based on the available documents (training registers, tracking sheets, prikazes, etc).
1. No IPC trainings conducted at this facility

2. Yes, for health care workers (clinical staff)

3. Yes, for non-clinical staff with access to patients or

wards at your facility (e.g. cleaners, auxiliary service

staff, administrative and managerial staff)

4. Yes, for family members, other care-givers or visitors

$$
\begin{aligned}
& \text { SKIP to } 23 \\
& \text { SKIP to } \\
& 23 \text { if } \\
& \text { only } 4 \text { is } \\
& \text { marked }
\end{aligned}
$$

2. Yes

1. No, interactive trainings only included written information and/or oral instructions and/or e-learning 2. Some trainings also included interactive sessions

3. All trainings included interactive sessions

1. External trainers from outside the facility

2. IPC team members

3. Non-IPC personnel

1. No assessment

2. Pre/post test

3. Post-training survey for participants

4. Compliance monitoring of IPC practices

1. All new HCWs are trained as part of new employee orientation

2. Ongoing regular training at least annually, but not mandatory

3. Ongoing mandatory training at least annually (not confirmed by any documentation)

4. Ongoing mandatory training at least annually (verified by documentation)

5. None of the above 


\begin{tabular}{|c|c|c|c|}
\hline$\#$ & Question & Answer & Skip \\
\hline 21 & $\begin{array}{l}\text { In general, which statement best describes when IPC training for non- } \\
\text { clinical staff in your facility is delivered? } \\
\text { SELECT ALL THAT APPLY } \\
\text { Please verify this answer based on the available documents (train- } \\
\text { ing registers, tracking sheets, prikazes, etc). }\end{array}$ & $\begin{array}{l}\text { 1. All new HCWs are trained as part of new employee } \\
\text { orientation } \\
\text { 2. Ongoing regular training at least annually, but not } \\
\text { mandatory } \\
\text { 3. Ongoing mandatory training at least annually (not } \\
\text { confirmed by any documents) } \\
\text { 4. Ongoing mandatory training at least annually (verified } \\
\text { by documentation) } \\
\text { 5. None of the above }\end{array}$ & \\
\hline 22 & $\begin{array}{l}\text { Do clinical trainings conducted at your facility for physicians working } \\
\text { in specialty areas (for example, surgery or anesthesiology) include } \\
\text { IPC? } \\
\text { For example, if there is a line insertion training, would HH and skin } \\
\text { prep standards be embedded in it, not just taught separately as } \\
\text { IPC training? }\end{array}$ & $\begin{array}{l}\text { 1. No clinical trainings for specialists conducted at the } \\
\text { facility } \\
\text { 2. Clinical trainings for specialists are conducted, but IPC } \\
\text { is not included } \\
\text { 3. Yes, in some trainings } \\
\text { 4. Yes, in all trainings }\end{array}$ & \\
\hline
\end{tabular}

Choose one answer

Please verify the answer based on the available documents.

IPC Monitoring and Audit

One role of the IPC team is to monitor or audit IPC practices, and provide feedback to staff in order to improve the quality of care and practice. An example of this is conducting hand hygiene observations to monitor staff compliance with appropriate hand hygiene practices.

Does this facility have an internal IPC monitoring/audit plan with any of the following?

SELECT ALL THAT APPLY

Please verify the answer based on the available documents. Only select options that were verified by the document review.

When was the last time there was an internal IPC monitoring/audit to assess compliance of any IPC practices at your facility?

Choose one answer

Did IPC staff document in any form implementation of monitoring/ audits conducted within the past 12 months documented?

Please ask for a copy of all the available IPC monitoring/audit reports conducted during the past 12 months

During the past 12 months, how often did you conduct monitoring/auditing of different IPC practices listed below in questions 25A-J?

Choose one answer for each of the following questions 25A-J

Please verify the answers based on the available documents.

25A Hand Hygiene Compliance

(using any observation tools)

If monitoring tools are not available (checklist and schedule), but facility staff claim to conduct monitoring frequently, mark "Periodically but no regular schedule"

25B Consumption/usage of alcohol-based hand rub or soap

If monitoring tools are not available (checklist and schedule), but facility staff claim to conduct monitoring frequently, mark "Periodically but no regular schedule"

25C Injection safety

If monitoring tools are not available (checklist and schedule), but facility staff claim to conduct monitoring frequently, mark "Periodically but no regular schedule"

25D Waste management

If monitoring tools are not available (checklist and schedule), but facility staff claim to conduct monitoring frequently, mark "Periodically but no regular schedule"
1. No facility monitoring/audit plan available

2. Yes with clear goals and objectives

3. Yes with tools to collect data in a systematic way (for example checklists)

4. Yes with clearly defined roles and responsibilities

5. Yes with work plan or schedule

1. Within the past 3 months

2. Within the past 6 months

3. Within the past 12 months

4. More than 12 months ago or never

1. No

2. Yes

\author{
1. Not conducted \\ 2. Periodically but no regular schedule \\ 3. Weekly \\ 4. Monthly \\ 5. Every 6 months \\ 6. Once a year \\ 1. Not conducted \\ 2. Periodically but no regular schedule \\ 3. Weekly \\ 4. Monthly \\ 5. Every 6 months \\ 6. Once a year \\ 1. Not conducted \\ 2. Periodically but no regular schedule \\ 3. Weekly \\ 4. Monthly \\ 5. Every 6 months \\ 6. Once a year \\ 1. Not conducted \\ 2. Periodically but no regular schedule \\ 3. Weekly \\ 4. Monthly \\ 5. Every 6 months \\ 6. Once a year
}




\begin{tabular}{|c|c|c|c|}
\hline$\#$ & Question & Answer & Skip \\
\hline$\overline{25 E}$ & $\begin{array}{l}\text { Cleaning of the ward environment } \\
\text { If monitoring tools are not available (checklist and schedule), but } \\
\text { facility staff claim to conduct monitoring frequently, mark "Peri- } \\
\text { odically but no regular schedule" }\end{array}$ & $\begin{array}{l}\text { 1. Not conducted } \\
\text { 2. Periodically but no regular schedule } \\
\text { 3. Weekly } \\
\text { 4. Monthly } \\
\text { 5. Every } 6 \text { months } \\
\text { 6. Once a year }\end{array}$ & \\
\hline $25 \mathrm{~F}$ & $\begin{array}{l}\text { Disinfection and sterilization of medical equipment/instruments } \\
\text { If monitoring tools are not available (checklist and schedule), but } \\
\text { facility staff claim to conduct monitoring frequently, mark "Peri- } \\
\text { odically but no regular schedule" }\end{array}$ & $\begin{array}{l}\text { 1. Not conducted } \\
\text { 2. Periodically but no regular schedule } \\
\text { 3. Weekly } \\
\text { 4. Monthly } \\
\text { 5. Every } 6 \text { months } \\
\text { 6. Once a year }\end{array}$ & \\
\hline $25 G$ & $\begin{array}{l}\text { Transmission-based precautions, isolation and cohorting (grouping) } \\
\text { of patients to prevent the spread of multidrug resistant organisms } \\
\text { (MDRO) } \\
\text { If monitoring tools are not available (checklist and schedule), but } \\
\text { facility staff claim to conduct monitoring frequently, mark "Peri- } \\
\text { odically but no regular schedule" }\end{array}$ & $\begin{array}{l}\text { 1. Not conducted } \\
\text { 2. Periodically but no regular schedule } \\
\text { 3. Weekly } \\
\text { 4. Monthly } \\
\text { 5. Every } 6 \text { months } \\
\text { 6. Once a year }\end{array}$ & \\
\hline $25 \mathrm{H}$ & $\begin{array}{l}\text { Consumption/usage of antimicrobial agents } \\
\text { If monitoring tools are not available (checklist and schedule), but } \\
\text { facility staff claim to conduct monitoring frequently, mark "Peri- } \\
\text { odically but no regular schedule" }\end{array}$ & $\begin{array}{l}\text { 1. Not conducted } \\
\text { 2. Periodically but no regular schedule } \\
\text { 3. Weekly } \\
\text { 4. Monthly } \\
\text { 5. Every } 6 \text { months } \\
\text { 6. Once a year }\end{array}$ & \\
\hline 251 & $\begin{array}{l}\text { Intravascular catheter insertion and/or care } \\
\text { If monitoring tools are not available (checklist and schedule), but } \\
\text { facility staff claim to conduct monitoring frequently, mark "Peri- } \\
\text { odically but no regular schedule" }\end{array}$ & $\begin{array}{l}\text { 1. Not conducted } \\
\text { 2. Periodically but no regular schedule } \\
\text { 3. Weekly } \\
\text { 4. Monthly } \\
\text { 5. Every } 6 \text { months } \\
\text { 6. Once a year }\end{array}$ & \\
\hline 25」 & $\begin{array}{l}\text { Wound dressing change } \\
\text { If monitoring tools are not available (checklist and schedule), but } \\
\text { facility staff claim to conduct monitoring frequently, mark "Peri- } \\
\text { odically but no regular schedule" }\end{array}$ & $\begin{array}{l}\text { 1. Not conducted } \\
\text { 2. Periodically but no regular schedule } \\
\text { 3. Weekly } \\
\text { 4. Monthly } \\
\text { 5. Every } 6 \text { months } \\
\text { 6. Once a year }\end{array}$ & \\
\hline 26 & \multicolumn{3}{|c|}{$\begin{array}{l}\text { During the past } 12 \text { months, how did you share results of these internal monitoring /auditing of IPC practices with the following } \\
\text { facility staff listed in questions } 26 \mathrm{~A}-\mathrm{E} \text { ? } \\
\text { SELECT ALL THAT APPLY }\end{array}$} \\
\hline $26 \mathrm{~A}$ & Clinical staff? & $\begin{array}{l}\text { 1. Did not share } \\
\text { 2. Shared orally during staff meetings } \\
\text { 3. Shared in a form of a written report }\end{array}$ & \\
\hline $26 B$ & Non-clinical staff that have direct contact with patients? & $\begin{array}{l}\text { 1. Did not share } \\
\text { 2. Shared orally during staff meetings } \\
\text { 3. Shared in a form of a written report }\end{array}$ & \\
\hline $26 C$ & Clinical managers/heads of department? & $\begin{array}{l}\text { 1. Did not share } \\
\text { 2. Shared orally during staff meetings } \\
\text { 3. Shared in a form of a written report }\end{array}$ & \\
\hline $26 \mathrm{D}$ & IPC committee? & $\begin{array}{l}\text { Did not share } \\
\text { Shared orally during staff meetings } \\
\text { Shared in a form of a written report }\end{array}$ & \\
\hline $26 \mathrm{E}$ & Non-clinical management (CEO, administration, board)? & $\begin{array}{l}\text { 1. Did not share } \\
\text { 2. Shared orally during staff meetings } \\
\text { 3. Shared in a form of a written report }\end{array}$ & \\
\hline 27 & $\begin{array}{l}\text { During the past } 12 \text { months, how often were your monitoring results } \\
\text { used to make unit/facility- specific plans for the improvement of IPC } \\
\text { practices? } \\
\text { Choose one answer } \\
\text { If yes, please ask to provide examples. Please verify the answers } \\
\text { based on the examples provided. }\end{array}$ & $\begin{array}{l}\text { 1. Always } \\
\text { 2. Sometimes } \\
\text { 3. Never }\end{array}$ & \\
\hline 28 & $\begin{array}{l}\text { Do you assess IPC safety cultural factors in your facility? } \\
\text { Show example of the surveys (Appendix 9) } \\
\text { Choose one answer }\end{array}$ & $\begin{array}{l}\text { 1. No } \\
\text { 2. Yes }\end{array}$ & \\
\hline
\end{tabular}




\begin{tabular}{|c|c|c|c|}
\hline$\#$ & Question & Answer & Skip \\
\hline \multicolumn{4}{|c|}{$\begin{array}{l}\text { HAI Surveillance } \\
\text { HAI surveillance programmes describe the incidence and prevalence of HAls in your facility, detect outbreaks in particular wards or } \\
\text { patient populations, guide IPC strategies and priorities, and assess the impact and effectiveness of interventions. }\end{array}$} \\
\hline 29 & $\begin{array}{l}\text { Does this facility conduct HAl surveillance? } \\
\text { Choose one answer } \\
\text { Please ask for all the available HAl surveillance guidelines or other } \\
\text { documents. Review the documents and answer question } 29 \mathrm{~A} .\end{array}$ & $\begin{array}{l}\text { 1. No } \\
\text { 2. Yes }\end{array}$ & SKIP to 38 \\
\hline $29 \mathrm{~A}$ & $\begin{array}{l}\text { Does HAl surveillance include any of the following? } \\
\text { Please verify the answers based on the available documents. } \\
\text { SELECT ALL THAT APPLY }\end{array}$ & $\begin{array}{l}\text { 1. List of priority healthcare associated infections which } \\
\text { are major causes of morbidity and mortality in the } \\
\text { facility } \\
\text { If prioritization process is not described in the docu- } \\
\text { ment, please ask to describe the process used to } \\
\text { identify infections which are major causes of morbid- } \\
\text { ity and mortality in the facility } \\
\text { 1. Standardized case-definitions (defined numerator and } \\
\text { denominator) } \\
\text { 2. Standardized data collection methods } \\
\text { 3. Processes to review data quality (for example, assess- } \\
\text { ment of case report forms, review of microbiology } \\
\text { results, denominator determination, etc.) } \\
\text { 4. Clearly defined roles and responsibilities of staff } \\
\text { involved in surveillance } \\
\text { 5. Annual work plan and schedule } \\
\text { 6. None of the above }\end{array}$ & SKIP to 38 \\
\hline 30 & \multicolumn{3}{|c|}{$\begin{array}{l}\text { Are you conducting } \mathrm{HAl} \text { surveillance in your facility for the following infection types listed in questions } 30 \mathrm{~A}-\mathrm{G} \text { ? } \\
\text { Choose one answer } \\
\text { Please ask for all the available HAl surveillance reports. }\end{array}$} \\
\hline $30 \mathrm{~A}$ & $\begin{array}{l}\text { Infections or colonization caused by multidrug-resistant pathogens } \\
\text { (non-susceptibility to at least one agent in three or more antimicro- } \\
\text { bial categories)? }\end{array}$ & $\begin{array}{l}\text { 1. No } \\
\text { 2. Yes }\end{array}$ & \\
\hline $30 \mathrm{~B}$ & $\begin{array}{l}\text { Device-associated infections (for example, catheter-associated urinary } \\
\text { tract infections, central line-associated bloodstream infections, } \\
\text { peripheral-line associated bloodstream infections, ventilator-associ- } \\
\text { ated pneumonia)? }\end{array}$ & $\begin{array}{l}\text { 1. No } \\
\text { 2. Yes }\end{array}$ & \\
\hline $30 C$ & Surgical site infections? & $\begin{array}{l}\text { 1. No } \\
\text { 2. Yes }\end{array}$ & \\
\hline $30 \mathrm{D}$ & $\begin{array}{l}\text { Infections that may affect health care workers (for example, hepatitis B } \\
\text { or C, HIV, influenza)? }\end{array}$ & $\begin{array}{l}\text { 1. No } \\
\text { 2. Yes }\end{array}$ & \\
\hline $30 \mathrm{E}$ & $\begin{array}{l}\text { Infections in targeted vulnerable patient populations (for example, } \\
\text { neonates, intensive care unit, immunocompromised, burn patients)? }\end{array}$ & $\begin{array}{l}\text { 1. No } \\
\text { 3. Yes }\end{array}$ & \\
\hline $30 \mathrm{~F}$ & $\begin{array}{l}\text { Local priority epidemic-prone infections (for example, norovirus, } \\
\text { influenza, tuberculosis)? }\end{array}$ & $\begin{array}{l}\text { 1. No } \\
\text { 2. Yes }\end{array}$ & \\
\hline $30 G$ & Clinically-defined (based on symptoms) infections? & $\begin{array}{l}\text { 1. No } \\
\text { 2. Yes }\end{array}$ & \\
\hline 31 & $\begin{array}{l}\text { What data sources do you use for your HAl surveillance? } \\
\text { SELECT ALL THAT APPLY } \\
\text { Please verify the answers based on the available documents. }\end{array}$ & $\begin{array}{l}\text { 1. Discharge diagnosis data } \\
\text { 2. Voluntary notification from physicians or nurses } \\
\text { 3. Ward-based assessments (e.g., chart review, discussion } \\
\text { with nurses or physicians, patient exam) } \\
\text { 4. Laboratory-based assessment (e.g., review of blood } \\
\text { cultures) } \\
\text { 5. None of these types of surveillance }\end{array}$ & \\
\hline 32 & $\begin{array}{l}\text { Have staff conducting HAI surveillance been trained in basic epide- } \\
\text { miology, surveillance and IPC (i.e. capacity to oversee surveillance } \\
\text { methods and manage/analyze/interpret data)? }\end{array}$ & $\begin{array}{l}\text { 1. No } \\
\text { 2. Yes }\end{array}$ & \\
\hline 33 & $\begin{array}{l}\text { During the past } 12 \text { months, how were your HAls surveillance data } \\
\text { shared with facility staff? } \\
\text { SELECT ALL THAT APPLY } \\
\text { Please ask for any available reports or staff meetings to verify the } \\
\text { answers }\end{array}$ & $\begin{array}{l}\text { 1. Not shared with facility staff } \\
\text { 2. Written reports } \\
\text { 3. Oral updates } \\
\text { 4. Presentation }\end{array}$ & \\
\hline 34 & $\begin{array}{l}\text { How often, do you provide up-to-date HAls surveillance information to } \\
\text { Choose one answer for questions } 34 \mathrm{~A}-\mathrm{E} \\
\text { Please verify the answers based on the available documents }\end{array}$ & the following groups listed in questions 34A-E? & \\
\hline
\end{tabular}




\begin{tabular}{|c|c|c|c|}
\hline$\#$ & Question & Answer & Skip \\
\hline $34 \mathrm{~A}$ & Clinical staff? & $\begin{array}{l}\text { 1. Never } \\
\text { 2. Quarterly } \\
\text { 3. Half-yearly } \\
\text { 4. Annually } \\
\text { 5. Periodically but no regular schedule }\end{array}$ & \\
\hline $34 \mathrm{~B}$ & Non-clinical staff that have direct contact with patients & $\begin{array}{l}\text { 1. Never } \\
\text { 2. Quarterly } \\
\text { 3. Half-yearly } \\
\text { 4. Annually } \\
\text { 5. Periodically but no regular schedule }\end{array}$ & \\
\hline $34 C$ & Clinical managers/heads of department? & $\begin{array}{l}\text { 1. Never } \\
\text { 2. Quarterly } \\
\text { 3. Half-yearly } \\
\text { 4. Annually } \\
\text { 5. Periodically but no regular schedule }\end{array}$ & \\
\hline $34 \mathrm{D}$ & IPC committee? & $\begin{array}{l}\text { 1. Never } \\
\text { 2. Quarterly } \\
\text { 3. Half-yearly } \\
\text { 4. Annually } \\
\text { 5. Periodically but no regular schedule }\end{array}$ & \\
\hline $34 \mathrm{E}$ & Non-clinical management? & $\begin{array}{l}\text { 1. Never } \\
\text { 2. Quarterly } \\
\text { 3. Half-yearly } \\
\text { 4. Annually } \\
\text { 5. Periodically but no regular schedule }\end{array}$ & \\
\hline 35 & $\begin{array}{l}\text { Are HAls surveillance data used to make unit/facility- specific plans for } \\
\text { the improvement of IPC practices? } \\
\text { Choose one answer } \\
\text { Please ask to provide examples and verify the answer }\end{array}$ & $\begin{array}{l}\text { 1. No } \\
\text { 2. Yes }\end{array}$ & \\
\hline 36 & $\begin{array}{l}\text { What best describes the microbiology laboratory capacity available to } \\
\text { support HAl surveillance in this facility? } \\
\text { Choose one answer }\end{array}$ & $\begin{array}{l}\text { 1. Laboratory is able to differentiate between gram posi- } \\
\text { tive and gram negative strains but cannot identify the } \\
\text { pathogen } \\
\text { 2. The laboratory can identify pathogens (e.g. isolate } \\
\text { identification) } \\
\text { 3. The laboratory can identify pathogens and antimicro- } \\
\text { bial susceptibility patterns }\end{array}$ & \\
\hline 37 & $\begin{array}{l}\text { Do you use any informatics/IT tools to support your HAl surveillance } \\
\text { (for example, electronic health records)? }\end{array}$ & $\begin{array}{l}\text { 1. No } \\
\text { 2. Yes }\end{array}$ & \\
\hline 38 & $\begin{array}{l}\text { How often do you analyze and report antimicrobial drug resistance } \\
\text { data? } \\
\text { Choose one answer }\end{array}$ & $\begin{array}{l}\text { 1. Never or rarely } \\
\text { 2. Regularly (e.g. quarterly/half a year/annually) }\end{array}$ & \\
\hline \multicolumn{4}{|c|}{$\begin{array}{l}\text { IPC Guidelines } \\
\text { Facility IPC guidelines provide recommendations for IPC practices in a facility and may be adapted from existing international and national } \\
\text { standards. Guidelines are often broad and high-level while standard-operating-procedures are more detailed step-by-step instructions } \\
\text { more specific to a certain setting }\end{array}$} \\
\hline 39 & $\begin{array}{l}\text { Does your facility have any IPC Guidelines? } \\
\text { Please ask for all the IPC Guidelines available at the facility. Review } \\
\text { the documents to verify the answer. }\end{array}$ & $\begin{array}{l}\text { 1. No } \\
\text { 2. Yes }\end{array}$ & SKIP to 44 \\
\hline 40 & $\begin{array}{l}\text { Which statement best describes the process you use in this facility to } \\
\text { develop or adapt IPC Guidelines? } \\
\text { Choose one answer }\end{array}$ & $\begin{array}{l}\text { 1. Facility uses international guidelines that have not } \\
\text { been adapted to facility context } \\
\text { 2. Facility uses national guidelines } \\
\text { 3. Facility develops its own guidelines }\end{array}$ & $\begin{array}{l}\text { SKIP to } 42 \\
\text { SKIP to } 42\end{array}$ \\
\hline 41 & $\begin{array}{l}\text { Who participates in the development and/or adaptation of the facility- } \\
\text { level Guidelines? } \\
\text { SELECT ALL THAT APPLY }\end{array}$ & $\begin{array}{l}\text { 1. IPC personnel } \\
\text { 2. Senior facility leadership } \\
\text { Clinical staff } \\
\text { 3. Facility management (e.g. Biosafety, Waste, WASH (i.e } \\
\text { those tasked with addressing water, sanitation and } \\
\text { health) } \\
\text { 4. Quality managers }\end{array}$ & \\
\hline 42 & $\begin{array}{l}\text { Do the facility training materials reflect the most updated IPC Guide- } \\
\text { lines? } \\
\text { Choose one answer }\end{array}$ & $\begin{array}{l}\text { 1. No training materials available } \\
\text { 2. No } \\
\text { 3. Yes } \\
\text { 4. Don't know }\end{array}$ & \\
\hline
\end{tabular}




\begin{tabular}{|c|c|c|c|}
\hline$\#$ & Question & Answer & Skip \\
\hline$\overline{43}$ & $\begin{array}{l}\text { Please describe the process you use to train HCW on IPC guidelines } \\
\text { when they are issued/updated? } \\
\text { Choose one answer } \\
\text { Please ask to see any training notes and/or list of participants and } \\
\text { agenda from the last training. }\end{array}$ & $\begin{array}{l}\text { 1. Trainings only included written information and/or oral } \\
\text { instructions } \\
\text { 2. Some trainings included interactive sessions } \\
\text { 3. All trainings included interactive sessions }\end{array}$ & \\
\hline 44 & $\begin{array}{l}\text { Does your facility have any IPC SOPs? } \\
\text { Choose one answer } \\
\text { Please ask for a copy of all the SOPs available at the facility. Review } \\
\text { the documents to verify the answer. }\end{array}$ & $\begin{array}{l}\text { 1. No } \\
\text { 2. Yes, SOPs not adapted to this facility } \\
\text { 3. Yes, adapted to this facility }\end{array}$ & $\begin{array}{l}\text { SKIP to } 46 \\
\text { SKIP to } 46\end{array}$ \\
\hline 45 & $\begin{array}{l}\text { Who participates in the development and/or adaptation of the facility- } \\
\text { level SOPs? } \\
\text { Choose one answer } \\
\text { SELECT ALL THAT APPLY }\end{array}$ & $\begin{array}{l}\text { 1. IPC personnel } \\
\text { 2. Senior facility leadership } \\
\text { 3. Clinical staff } \\
\text { 4. Facility management (e.g. Biosafety, Waste, WASH (i.e } \\
\text { those tasked with addressing water, sanitation and } \\
\text { health) } \\
\text { 5. Quality managers }\end{array}$ & \\
\hline
\end{tabular}

\section{Multimodal strategies}

The term multimodal strategy refers to the implementation of several elements or components in an integrated way with the aim of improving an outcome and changing behavior. This multimodal strategy includes components such as system change which is the availability of infrastructure and supplies to enable IPC practices; education and training of healthcare workers and other hospital staff; monitoring of infrastructure, practices, processes, outcomes, and providing data feedback; reminders in the workplace; and culture change within the facility. In other words, the strategy involves "building" the right system, "teaching" the right things, "checking" the right things, "selling" the right messages, and ultimately "living" IPC throughout the entire health system.

46 For hand hygiene $(\mathrm{HH})$ improvement activities, does your facility have any or all of the following elements listed in questions 46A-E?

SELECT ALL THAT APPLY for questions 46A-E

46A System change

Education and training on hand hygiene practices

46C Monitoring of $\mathrm{HH}$ compliance and feedback

Communications and reminders

Safety climate and culture change

How frequently is the WHO Hand Hygiene Self-Assessment Framework Survey conducted?

Choose one answer

Show the Survey to remind people what it is.

Please verify the answers based on the available documents.

48
1. Element not included in work activities

2. Interventions to ensure the necessary infrastructure and continuous

3. Availability of supplies

4. Interventions to ensure optimal use and accessibility and prevent human error

Please ask to provide examples to verify the answer

1. Element not included in work activities

2. Written information and/or oral instruction and/or e-learning

3. Interactive training sessions (includes simulation and/ or bedside training)

1. Element not included in work activities

2. Audits of hand hygiene conducted

3. Audit results shared and discussed with health care workers and key players

1. Element not included in work activities

2. Reminders, posters, or other tools used to promote or raise awareness of hand hygiene

3. Additional methods/initiatives to improve team communication across units and specialties (for example, multidisciplinary rounds?)

1. Element not included in work activities

2. Managers/leaders (i.e. head of the hospital, chief clinicians, head of nursing) show visible support and act as champions and role models, promoting an adaptive approach and strengthening a culture that supports hand hygiene

3. Facility staff (clinical and non-clinical) are empowered to participate in hand hygiene improvement activities

1. Never

2. Periodically but not annually or on a regular schedule

3. At least annually

As far as your injection safety improvement activities, does your facility have any or all of the following elements listed in questions 48A-E?

SELECT ALL THAT APPLY for questions 48A-E 


\begin{tabular}{|c|c|c|c|}
\hline$\#$ & Question & Answer & Skip \\
\hline$\overline{48 \mathrm{~A}}$ & System change & $\begin{array}{l}\text { 1. Element not included in work activities } \\
\text { 2. Interventions to ensure the necessary infrastructure } \\
\text { and continuous availability of supplies } \\
\text { 3. Interventions to ensure optimize use and accessibility } \\
\text { and prevent human error } \\
\text { Please ask to provide examples to verify the answer }\end{array}$ & \\
\hline $48 \mathrm{~B}$ & Education and training on injection safety & $\begin{array}{l}\text { 1. Element not included in work activities } \\
\text { 2. Written information and/or oral instruction and/or } \\
\text { e-learning only } \\
\text { 3. Interactive training sessions (includes simulation and/ } \\
\text { or bedside training) }\end{array}$ & \\
\hline $48 \mathrm{C}$ & $\begin{array}{l}\text { Monitoring of injection safety compliance and feedback } \\
\text { GIVE THE Injection Safety CHECKLIST as an example (Appendix 8) }\end{array}$ & $\begin{array}{l}\text { 1. Element not included in work activities } \\
\text { 2. Audits of injection safety conducted } \\
\text { 3. Results shared and discussed with health care workers } \\
\text { and key players }\end{array}$ & \\
\hline $48 \mathrm{D}$ & Communications and reminders & $\begin{array}{l}\text { 1. Element not included in work activities } \\
\text { 2. Reminders, posters, or other tools to promote or raise } \\
\text { awareness of injection safety } \\
\text { 3. Additional methods/initiatives to improve team com- } \\
\text { munication across units and disciplines (for example, } \\
\text { by facilitating multidisciplinary rounds) }\end{array}$ & \\
\hline $48 \mathrm{E}$ & Safety climate and culture change & $\begin{array}{l}\text { 1. Element not included in work activities } \\
\text { 2. Managers/leaders (head of the hospital, chief clinician } \\
\text { and head of nursing) show visible support and act as } \\
\text { champions and role models, promoting an adaptive } \\
\text { approach and strengthening a culture that supports } \\
\text { injection safety } \\
\text { 3. Facility staff (clinical and non-clinical) are empowered } \\
\text { to participate in injection safety improvement activities }\end{array}$ & \\
\hline 49 & $\begin{array}{l}\text { Are your quality improvement staff involved in IPC activities? } \\
\text { Choose one answer }\end{array}$ & $\begin{array}{l}\text { 1. No quality improvement unit/staff at the facility } \\
\text { 2. Quality improvement unit/staff available, but not } \\
\text { involved in IPC } \\
\text { 3. Quality improvement unit/staff available and involved } \\
\text { in IPC }\end{array}$ & \\
\hline
\end{tabular}

IPC Infrastructure, Staffing, Workload and Supplies

Finally, I would like to ask a few questions about the facility's infrastructure, and availability of staff and IPC supplies.

50 Are water services available at all times and of sufficient quantity for all $\quad 1$. No, available on average $<5$ days per week uses (e.g., hand washing, drinking, personal hygiene, medical activi- $\quad$ 2. Yes, available on average $\geq 5$ days per week or every ties, sterilization, decontamination, cleaning and laundry)? Choose one answer

day but not of sufficient quantity

3. Yes, every day and of sufficient quantity

51 Is a reliable safe drinking water station present and accessible for staff, patients and families at all times and in all locations/wards?

Choose one answer

1. No, not available

2. Sometimes, or only available in some places or not available for all users

3. Yes, accessible at all times and for all wards/groups

52 Is bed occupancy in your facility kept to one patient per bed? Choose one answer

1. No

2. Yes, but not in all departments

3. Yes, for all units including pediatrics/neonatal and emergency

53 Do you place patients in beds outside of the room (in the corridor) Choose one answer

1. Never

2. Sometimes, or only in some departments

54 Do you ensure adequate spacing of $>1$ meter between patient beds? Choose one answer

1. No

2. Yes, but not in all departments

3. Yes, for all units including pediatrics and emergency

55 Do you have a responsible person/party to assess and respond when adequate bed capacity is exceeded?

Choose one answer

1. No

2. Yes the clinical head of department is responsible

3. Yes, the hospital administration/management is responsible

56 Are functioning hand hygiene stations (e.g., alcohol-based hand rub solution or soap and water with a basin/pan and clean single-use towels) available at all points of care?

1. No

2. Yes, stations present, but supplies are not always available

Choose one answer

3. Yes, always available 


\begin{tabular}{ll}
\hline$\#$ & Question \\
\hline 57 & $\begin{array}{l}\text { In your facility, are } \geq 4 \text { toilets or improved latrines (clean and } \\
\text { functional) available for outpatient settings or } \geq 1 \text { per } 20 \text { users for } \\
\text { inpatient settings? } \\
\text { Choose one answer }\end{array}$
\end{tabular}

In your health care facility, is sufficient energy/power supply available at day and night for all uses

Answer

(for example, pumping and boiling water, sterilization and decontamination, incineration or alternative treatment technologies, electronic medical devices, general lighting of areas where health care procedures are performed to ensure safe provision of health care and lighting of toilet hospitals and showers)?

\section{Choose one answer}

Is functioning environmental ventilation available in-patient care areas, 1. No including natural (using natural forces to vent air through windows/ doors) or mechanical ventilation?

\section{Choose one answer}

60 For floors and horizontal work surfaces, is there a visible record of cleaning, signed by the cleaners each day?

\section{Choose one answer}

61 Are appropriate and well-maintained materials for cleaning (for example, detergent, mops, buckets, etc.) available?

\section{Choose one answer}

Do you have single patient rooms or rooms for cohorting (grouping based on common illness) patients with similar pathogens if the number of isolation rooms is insufficient or unavailable (for example, TB, measles, cholera)?

\section{SELECT ALL THAT APPLY}

63 Do you have functional waste collection containers for non-infectious (general) waste, infectious waste and, sharps waste at all waste generation points?

Choose one answer

64 Is a functional burial pit/fenced waste dump or municipal pick-up available for disposal of non-infectious (non-hazardous/general waste)?

\section{Choose one answer}

Is outsourced waste disposal or an incinerator or alternative treatment for infectious and sharp waste (for example, an autoclave) functional and of a sufficient capacity?

\section{Choose one answer}

Are at least two pairs of household cleaning gloves and one pair of overalls or apron and boots in a good state and available for each cleaning and waste disposal staff member?

\section{Choose one answer}

Is wastewater safely managed using on-site treatment (for example, septic tank followed by drainage pit) or sent to a functioning sewer system?

\section{Choose one answer}

Does your health care facility provide a dedicated decontamination area and/or sterile supply department for the decontamination and sterilization of medical devices and other items/equipment?

\section{Choose one answer}

Do you reliably have sterile and disinfected equipment ready for use? Choose one answer

2. Yes, in some patient care services

3. Yes, in all patient care areas

1. No record of floors and surfaces being cleaned

2. Record exists, but is not completed daily or is outdated

3. Yes, record completed daily

1. No materials available

2. Yes, available but not well maintained (not labeled, broken, or dirty, etc.)

3. Yes, available and well-maintained

1. No single rooms and no rooms for cohorting (grouping) patients

2. Rooms suitable for patient cohorting available

3. Single rooms are available

1. No bins or separate sharps disposal

2. Separate bins present but lids missing or more than 3/4 full; or two bins (instead of three); or bins at some but not all waste generation points.

3. Yes, all three containers

1. No pit or other disposal method used

2. Pit in facility but insufficient dimensions; pits/dumps overfilled or not fenced/locked; or irregular municipal waste pick up

3. Yes

1. No, none present

2. Yes

1. No, not available

2. Yes, available but in poor condition

3. Yes, in good condition

1. No, not present

2. Yes, available but in poor condition

3. Yes, in good condition

1. No, not present

2. Yes, present, but not functioning 3. Yes

1. Available on average $<5$ days per week

2. Available on average $\geq 5$ days per week or every day,

but not of sufficient quantity

3. Available every day and of sufficient quantity

Are disposable items available when necessary? (for example, injection 1. Not available safety devices (such as sharps injury protection syringes and reuse prevention syringes), examination gloves)

2. Only sometimes available

3. Continuously available 
General questions

Before we go around the facility, we would like to ask you a couple of more general questions.

\section{PART 2}

The checklist should be completed by the assessment team based on direct observations during a random walk around the facility. It is recommended that the random walk will include visits to one ICU (if available) and a typical ward (department). In case of hospitals that have pediatric and adult wards, the team needs to visit one adult ward and one pediatric ward. In each ward, the team must check a minor procedures room and 2-5 patient rooms.

Please check the availability of the following:

73 Visible reminders, posters, or other tools to promote or raise awareness of hand hygiene

\section{Choose one answer}

74 Visible reminders, posters, or other tools to promote or raise awareness of injection safety

\section{Choose one answer}

75 Any patients in beds outside of the room (in the corridor)

76 More than 1 meter between patient beds?

77 Hand hygiene stations (e.g., alcohol-based handrub solution or soap and water with a basin/pan and clean single-use towels) available at all points of care?

\section{Choose one answer}

78 Functional waste collection containers for non-infectious (general) waste, infectious waste and, sharps waste at all waste generation points?

79 For floors and horizontal work surfaces, a visible record of cleaning, signed by the cleaners each day

\author{
1. Not available \\ 2. Available at some hand hygiene stations observed \\ 3. Available at all hand hygiene stations observed \\ 1. Not available \\ 2. Available at some units/wards/departments observed \\ 3. Available at all units/wards/departments observed \\ 1. No \\ 2. Yes \\ 1. No \\ 2. Yes, but not in all departments \\ 3. Yes, for all units including pediatrics and emergency \\ 1. Not available \\ 2. Yes, stations present, but supplies are not always available \\ 3. Yes, always available \\ 1. No bins or separate sharps disposal \\ 2. Separate bins present but lids missing or more than 3/4 full; or \\ two bins (instead of three); or bins at some but not all waste \\ generation points. \\ 3. Yes, all three containers \\ 1. No record of floors and surfaces being cleaned \\ 2. Record exists, but is not completed daily or is outdated \\ 3. Yes, record completed daily
}

Received: 18 June 2020 Accepted: 26 December 2020

Published online: 24 February 2021

\section{References}

1. Aghdassi SJS, Hansen S, Bischoff P, Behnke M, Gastmeier P. A national survey on the implementation of key infection prevention and control structures in German hospitals: results from 736 hospitals conducting the WHO Infection Prevention and Control Assessment Framework (IPCAF). Antimicrob Resist Infect Control. 2019;8(1):73. https://doi.org/10.1186/ s13756-019-0532-4.

2. Aghdassi SJS, Grisold A, Wechsler-Fördös A, Hansen S, Bischoff P, Behnke $M$, Gastmeier P. Evaluating infection prevention and control programs in Austrian acute care hospitals using the WHO Infection Prevention and Control Assessment Framework. Antimicrob Resist Infect Control. 2020;9(1):92. https://doi.org/10.1186/s13756-020-00761-2.

3. Akhvlediani T, Akhvlediani N, Kuchuloria T. Important aspect of health care associated infections in georgia with the focus on ventilator-associated pneumonia (review). Georgian Med News. 2016:258:80-4.

4. Allegranzi B, Kilpatrick C, Storr J, Kelley E, Park BJ, Donaldson L, et al. Global infection prevention and control priorities 2018-22: a call for action. Lancet Global Health. 2017;5(12):e1178-80.

5. Alp E, Damani N. Healthcare-associated infections in intensive care units: epidemiology and infection control in low-to-middle income countries. J Infect Dev Ctries. 2015;9(10):1040-5.

6. Bazeley P. Integrating analyses in mixed methods research. Thousand Oaks: Sage; 2017.

7. Brown S, Kurtsikashvili G, Alonso-Echanove J, Ghadua M, Ahmeteli L, Bochoidze T, et al. Prevalence and predictors of surgical site infection in Tbilisi, Republic of Georgia. J Hosp Infect. 2007;66(2):160-6. https://doi. org/10.1016/j.jhin.2007.03.007.

8. Butsashvili M, Kamkamidze G, Umikashvili L, Gvinjilia L, Kankadze K, Berdzuli N. Knowledge of health care-associated infections among Georgian obstetricians and gynecologists. J Infect Dev Ctries. 2010;4(05):329-33.

9. Cosgrove SE. The relationship between antimicrobial resistance and patient outcomes: mortality, length of hospital stay, and health care costs. Clin Infect Dis. 2006;42(2):82-9. https://doi.org/10.1086/499406. 
10. Cromer AL, Latham SC, Bryant KG, Hutsell S, Gansauer L, Bendyk HA, et al. Monitoring and feedback of hand hygiene compliance and the impact on facility-acquired methicillin-resistant Staphylococcus aureus. Am J Infect Control. 2008;36(9):672-7.

11. Gvinjilia L, Nasrullah M, Sergeenko D, Tsertsvadze T, Kamkamidze G, Butsashvili M, et al. National progress toward hepatitis C eliminationGeorgia, 2015-2016. MMWR Morb Mortal Wkly Rep. 2016;65(41):1132-5. https://doi.org/10.15585/mmwr.mm6541a2.

12. Hartmann CW, Meterko M, Rosen AK, Zhao S, Shokeen P, Singer S, Gaba DM. Relationship of hospital organizational culture to patient safety climate in the Veterans Health Administration. Med Care Res Rev. 2009;66(3):320-38.

13. Huis A, Hulscher M, Adang E, Grol R, van Achterberg T, Schoonhoven L. Cost-effectiveness of a team and leaders-directed strategy to improve nurses' adherence to hand hygiene guidelines: a cluster randomised trial. Int J Nurs Stud. 2013;50(4):518-26. https://doi.org/10.1016/j.ijnur stu.2012.11.016.

14. Kandelaki G, Butsashvili M, Geleishvili M, Avaliani N, Macharashvili N, Topuridze M, et al. Nosocomial Infections in Georgia; a retrospective study of microbiological data from four major tertiary care hospitals in Tbilisi, capital of Georgia. Infect Control Hosp Epidemiol. 2011;32(9):9334. https://doi.org/10.1086/661788.

15. Laxminarayan R, Duse A, Wattal C, Zaidi AK, Wertheim HF, Sumpradit N, et al. Antibiotic resistance-the need for global solutions. Lancet Infect Dis. 2013;13(12):1057-98. https://doi.org/10.1016/s1473-3099(13)70318-9.

16. Macharashvili N, Kourbatova E, Butsashvili M, Tsertsvadze T, McNutt LA, Leonard MK. Etiology of neonatal blood stream infections in Tbilisi, Republic of Georgia. Int J Infect Dis. 2009;13(4):499-505. https://doi. org/10.1016/j.jiji.2008.08.020.

17. Magill SS, Edwards JR, Bamberg W, Beldavs ZG, Dumyati G, Kainer MA, et al. Multistate point-prevalence survey of health care-associated infections. N Engl J Med. 2014;370(13):1198-208.

18. McFadden KL, Henagan SC, Gowen CR III. The patient safety chain: transformational leadership's effect on patient safety culture, initiatives, and outcomes. J Oper Manag. 2009;27(5):390-404.

19. Mdivani N, Zangaladze E, Volkova N, Kourbatova E, Jibuti T, Shubladze N, et al. High prevalence of multidrug-resistant tuberculosis in Georgia. Int J Infect Dis. 2008;12(6):635-44. https://doi.org/10.1016/j.ijid.2008.03.012.

20. Mehrad B, Clark NM, Zhanel GG, Lynch JP 3rd. Antimicrobial resistance in hospital-acquired gram-negative bacterial infections. Chest. 2015;147(5):1413-21. https://doi.org/10.1378/chest.14-2171.

21. Miles MB, Huberman AM, Saldana J. Qualitative data analysis. Thousand Oaks: Sage; 2014.

22. Miteniece E, Pavlova M, Shengelia L, Rechel B, Groot W. Barriers to accessing adequate maternal care in Georgia: a qualitative study. BMC Health Serv Res. 2018;18(1):631. https://doi.org/10.1186/s12913-018-3432-z.

23. Mitruka K, Tsertsvadze T, Butsashvili M, Gamkrelidze A, Sabelashvili P, Adamia $\mathrm{E}$, et al. Launch of a nationwide hepatitis $C$ elimination programGeorgia, April 2015. MMWR Morb Mortal Wkly Rep. 2015;64(28):753-7.

24. Olans RN, Olans RD, DeMaria JA. The critical role of the staff nurse in antimicrobial stewardship —unrecognized, but already there. Clin Infect Dis. 2016;62(1):84-9. https://doi.org/10.1093/cid/civ697.

25. Pittet D, Hugonnet S, Harbarth S, Mourouga P, Sauvan V, Touveneau S, Perneger TV. Effectiveness of a hospital-wide programme to improve compliance with hand hygiene. Lancet. 2000;356(9238):1307-12.

26. Revazishvili T, Bakanidze L, Gomelauri T, Zhgenti E, Chanturia G, Kekelidze $\mathrm{M}$, et al. Genetic background and antibiotic resistance of Staphylococcus aureus strains isolated in the Republic of Georgia. J Clin Microbiol. 2006;44(10):3477-83. https://doi.org/10.1128/jcm.01030-06.

27. Richards B, Sebastian B, Sullivan H, Reyes R, D'Agostino JF, Hagerty T. Decreasing catheter-associated urinary tract infections in the neurological intensive care unit: one unit's success. Critical care nurse. 2017;37(3):42-8.
28. Rosenthal VD, Desse J, Maurizi DM, Chaparro GJ, Orellano PW, Chediack $V$, et al. Impact of the International Nosocomial Infection Control Consortium (INICC)'s multidimensional approach on rates of central lineassociated bloodstream infection in 14 intensive care units in 11 hospitals of 5 cities in Argentina. Infect Control Hosp Epidemiol. 2018;39(4):445-51. https://doi.org/10.1017/ice.2017.298.

29. Rukhadze T. An overview of the health care system in Georgia: expert recommendations in the context of predictive, preventive and personalised medicine. EPMA J. 2013;4(1):8. https://doi.org/10.1186/1878-5085-4-8.

30. Schaffner J, Chochua S, Kourbatova EV, Barragan M, Wang YF, Blumberg HM, et al. High mortality among patients with positive blood cultures at a children's hospital in Tbilisi, Georgia. J Infect Dev Ctries. 2009;3(4):267-72.

31. Storr J, Kilpatrick C, Allegranzi B, Syed SB. Redefining infection prevention and control in the new era of quality universal health coverage. J Res Nurs. 2016;21(1):39-52.

32. Storr J, Twyman A, Zingg W, Damani N, Kilpatrick C, Reilly J, et al. Core components for effective infection prevention and control programmes: new WHO evidence-based recommendations. Antimicrob Resist Infect Control. 2017;6(1):6.

33. Suetens C, Hopkins S, Kolman J, Diaz Högberg L. European Centre for Disease Prevention and Control. Point prevalence survey of healthcare associated infections and antimicrobial use in European acute care hospitals. Stockholm: ECDC; 2013

34. Tomczyk S, Aghdassi S, Storr J, Hansen S, Stewardson AJ, Bischoff P, et al. Testing of the WHO Infection Prevention and Control Assessment Framework at acute healthcare facility level. J Hosp Infect. 2020;105(1):83-90. https://doi.org/10.1016/j.jhin.2019.12.016.

35. van't Hoog A, Bergval I, Tukvadze N, Sengstake S, Aspindzelashvili R, Anthony R, Cobelens F. The potential of a multiplex high-throughput molecular assay for early detection of first and second line tuberculosis drug resistance mutations to improve infection control and reduce costs: a decision analytical modeling study. BMC Infect Dis. 2015. https://doi. org/10.1186/s12879-015-1205-4.

36. WHO. Guidelines on core components of infection prevention and control programmes at the national and acute health care facility level. World Health Organization. (2016). Retrieved from https://www.who.int/gpsc/ ipc-components/en/.

37. WHO. Improving infection prevention and control at the health facility: interim practical manual supporting implementation of the WHO guidelines on core components of infection prevention and control programmes. World Health Organization. (2018). Retrieved from https:// apps.who.int/iris/handle/10665/279788.

38. WHO. Infection prevention and control assessment framework at the facility level. World Health Organization. (2018). Retrieved from https:// www.who.int/infection-prevention/tools/core-components/IPCAF-facil ity.PDF.

39. Yinnon A, Wiener-Well Y, Jerassy Z, Dor M, Freund R, Mazouz B, et al. Improving implementation of infection control guidelines to reduce nosocomial infection rates: pioneering the report card. J Hosp Infect. 2012;81(3):169-76.

40. Zingg W, Holmes A, Dettenkofer M, Goetting T, Secci F, Clack L, et al. Hospital organisation, management, and structure for prevention of health-care-associated infection: a systematic review and expert consensus. Lancet Infect Dis. 2015;15(2):212-24.

\section{Publisher's Note}

Springer Nature remains neutral with regard to jurisdictional claims in published maps and institutional affiliations. 